\title{
胸郭出口症候群に対する我々の診断法と 手術的治療
}

\author{
福岡大学医学部整形外科 \\ 南川博 道・竹下満 \\ 岩本英明・高岸直人
}

\section{Diagnosis and Surgical Treatment of Thoracic Outlet Syndrome}

by

Hiromichi Minamikawa, Mitsuru Takeshita

Hideaki Iwamoto and Nahoto Takagishi

Department of Orthopedic Surgery, School of Medicine, Fukuoka University, Fukuoka, Japan

Thoracic outlet syndrome has been diagnosed with combination of the datailed present history (particularly the condition of onset, and relation between increase of symptoms and the arm position), the reproduction of symptoms by several advocated tests for the vessel, shooting pain below the elbow in Morley's test, positive within one minute in the 3-minute stress test, negation of differential diagnosis and the effects of scalenus block.

Furthermore, we confirmed the diagnosis with positive findings of neurography of the brachial plexus.

Clinical symptoms were analyzed in 74 cases over 6 months postoperatively. 58 out of 74 cases $(78.4 \%)$ showed good-to-excellent results. Improve-ratio of backache was lower than the other symptoms.

We consider that at least three to four years follow-up period must be need after operation, because the present study showed that postoperative results were unstable at one to two years after operation.

\section{はじめに}

胸郭出口症候群は肩から上肢にかけて脱力，しびれ や痛みなど多彩な症状を呈するものでそれ故に診断に 苦虑する事も少なくない，そこで今回本症候群に対す る我々の診断法と当科開設以来の手術症例を調査した のでその結果を報告する.

\section{我々の診断法}

症状は上肢の脱力，しびれ，痛み，肩甲部痛および 上肢の浮腫・冷感など多彩であるが症状の発現・消長 が上肢の肢位と関連をもつ事が特長であり，又神経麻 痺症状はほとんど来ない.テスト法としては脈管テス
トとして Adson's test, Wright's test, Allen's test, Eden's test, 腕神経叢の刺激テストとしての Morley's test, Roos の提唱した 3 分間テストなどがありそれぞ れ特長をもっている. Adson's testやEden's test は本症例でも陽性率が低く, 陽性であれば本症を疑え るが, Wright's test, Allen's testでは正常者でも40 \%以上は陽性となるので，テスト施行時の症状再現性 のチェックが重要である11. Morley’s testでは䅡部 疾患を否定でき，丹以上すなわち肘以下への放散性を 得る事が診断に重要である。また 3 分間テストでは 60 秒以内を有意と考えているが肩周辺疾患でも陽性に出 うるので施行に際しては症状の再現性および手指の色 の変化のチェックが重要である. 補助診断法としては, 
血管系に対しては鎖骨下動脈造影，鎖骨下静脈造影お よび指尖容積脈波があり, 又神経系に対しては腕神経 叢造影, 尺骨神経伝導速度, 筋電図がありそれぞれ特 長がみられる. 動脈造影は本症の大部分が神経症状を主 体とする事，および立位での検査が行ないにくく陽性率 が低い事より我々は適応を循環障害例に限っている. 又 神経伝導速度は Urschel らが本症の診断に有用として いるが我々の経験では術前と術後，健側と患側の比較 を行なってもほとんど差は出ていない。そこで, 本症 の症状の主体は神経症状であるため, 腕神経叢の圧迫 の状態を客観的に把握する目的で我々は昭和56年より 腕神経叢部の造影を用いている.また鑑別疾患として は, 頚椎疾患, 肩周辺疾患 (特に動摇肩), 肩甲背筋痛, 末梢神経絞扼性神経炎（手根管症候群, 肘部管症候群 など）などがありこれらのものを除外せねばならない. 以上の事から我々は本症の診断法として症状の発現 や増減が上肢の肢位・動作と関連あること，脈管テス トでの症状の再現性, Morley's test での前腕以下へ の放散， 3 分間テストでの 1 分以内陽性，他疾患の否 定および斜角筋ブロックの効果を総合して考え，腕神 経叢造影で確認している.(表 1)

表 1 胸郭出口症候群の診断法

1. 症状の発現や増減が, 上肢の肢位・動作と関連性あり.

2. 脈管テストでの陽性所見とともに, 症状の再現性をみ ること.

3. Morley's test での前腕以下への放散性

4. 3 分間テストでの 1 分以内の陽性（保持不能）

5 . 他疾患 (特に頸椎・肩周辺疾患) の否定

6 . 斜角筋でブロックでの効果

7 . 腕神経叢造影

\section{本症候群の手術的治療}

上記の方法により本症と診断された症例には表 2 の ような保存的治療を行なっているが，これらに抵抗性 で日常生活での苦痛の強い症例には手術の必要がある。 1 . 症例

昭和 48 年以来，当科で手術を施行し術後 6 ケ月以上 経過している症例は82症例，95側で男性33例（手術時 平均年令39.2才），女性49例（同30.0才）であった。手 術々式（表 3 ）では, 第 1 肋骨切除術が84側と最も多 くこの中には頮胁切除の合併が 5 側, 肋骨奇形の為に
表 2 胸郭出口症候群の保存的治療

1 . 日常生活指導

2 . 肩甲帯筋の筋力増強訓練

3. 温熱

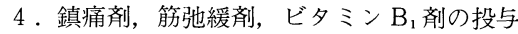

5.ブロック（腕神経叢，斜角筋，星状神経節）

表 3 手術術式

第 1 助骨切除術……………………..8 84側

第 1 肋骨切除十小胸筋切離術…………. 3

第 1 肋骨切除十腕神経叢剝離術………1 1

斜角筋切離術……………………... 6

小胸筋切離術………......................

合 計 95側

（他医で既に斜角筋切離術を

受けているもの 10側）

表 4 術後成績

(術後 6 ケ月以上経過例)

症 例 数: 63症例 74 側

術後経過期間： 6 个月～ 14 年 2 ケ月

(平均 5 年 3 ケ月)

\begin{tabular}{|r|l|l|}
\hline & & 計74人 \\
\hline 優 & 完全寬解 & 18人 $(24.3 \%)$ \\
\hline 良 & 症状の一部残存 & 40 人 $(54.1 \%)$ \\
\hline 可 & 症状残るも術前比し良い & 12 人 $(16.2 \%)$ \\
\hline 不可 & 不変または悪化 & 4 人 $(5.4 \%)$ \\
\hline
\end{tabular}

第 2 肋骨も切除した 1 側を含んでいる．腕神経叢剝離 を必要とした 1 側は鎖骨々折術後の症例である。その うち今回予後調查のできた症例は74例であった.

2. 結果および考察

a ) 総合評価（表 4 ）

74 側の術後平均経過期間は 5 年 3 カ月であり, 術後 成績を表の如く優・良・可・不可の 4 段階として判定 した，良は術前症状の一部がわずかに残っているもの をさしている．74側の結果は優および良を症状改善と みなすと改善率は $78.4 \%$ で，5 年前の調査時の約 $60 \%{ }^{23}$ に比較し向上がみられる. 不可の 4 例のうち 2 例は第 1 肋骨再生例であり， 1 例は再手術により優に，1例 は再手術術後症状残存し可となっている. 1 例は psychological factor が存在し手術適応に問題があった症 
表 5 術前症状及びその重症度

\begin{tabular}{|c|c|c|c|c|c|}
\hline 点数 & 肩甲部痛 & 肩脱力 & 上肢のしびれ & 上肢脱力 & 浮腫·冷感 \\
\hline 0 & 9 & 14 & 15 & 12 & $51(68.9 \%)$ \\
\hline 1 & 6 & 8 & 3 & 6 & 2 \\
\hline 2 & 20 & 10 & 11 & 8 & 10 \\
\hline 3 & $39 \int \%$ & $42 \int \%$ & 45 & $48 \% \%$ & 11 \\
\hline 計 & 74 人 & 74 人 & 74人 & 74人 & 74人 \\
\hline
\end{tabular}

0 ：なし

1 ：時々ある

2 ：常時あるが弱い

3 : 常時あり強い

表 6 症状別改善度

\begin{tabular}{|c|c|c|c|c|c|}
\hline & \multicolumn{4}{|c|}{ 改 善 度 (点) } & \multirow[b]{2}{*}{ 計（人） } \\
\hline & 3 & 2 & 1 & 0 & \\
\hline 肩甲部痛 & 11 & $\frac{20}{\%}$ & 22 & 10 & 63 \\
\hline 肩脱力 & $\frac{21}{75}$ & $\frac{21}{\%}$ & 9 & 5 & 56 \\
\hline 上肢のしびれ & 23 & $\frac{17}{\%}$ & 13 & 5 & 58 \\
\hline 上肢脱力 & & ${ }^{26}$ & 9 & 6 & 60 \\
\hline 浮腫·冷感 & & $\frac{11}{\%}$ & 4 & 1 & 21 \\
\hline
\end{tabular}

例で，残り 1 例は鎖骨々折術後に第 1 肋骨切除および 腕神経叢剝離術を行ない症状 1 時改善するも 4 力月後 再発した症例である。

b ) 術前症状およびその重症度（表 5 ）

代表的な自覚症状として肩甲部痛, 肩の脱力, 上肢 のしびれ，上肢の脱力および浮腫・冷感の項目を選び 表のような 0 から 3 点までの 4 段階に分類した。重症 度分類では浮腫・冷感の項目を除き術前症例 50 人, 70 \%以上が 2 点以上を有していたが, 浮腫・冷感を有し

ている症例は $30 \%$ であった。

c）症状別改善度（表 6 ）

次に症状別改善度をみてみた。ここでの改善度は術 後と術前の重症度の点数の差で表現している．肩およ び上肢の脱力，上肢のしびれは良く改善されている

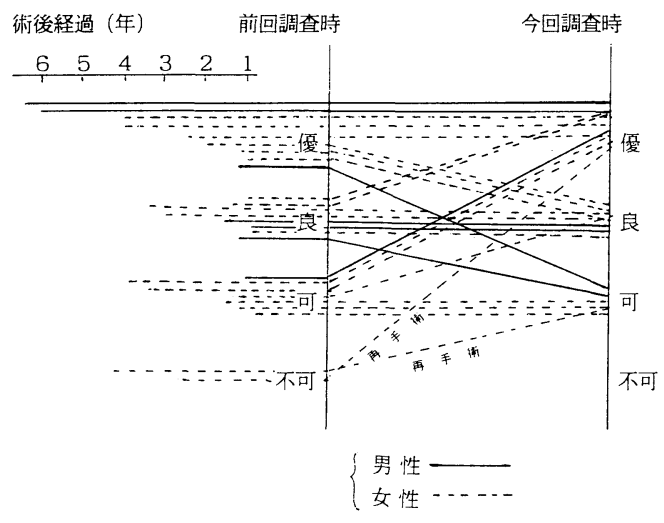

図 1 手術成績の経年的推移

が，肩甲部痛は改善度悪く，軽度改善例が多かった。

d) 術後成績の経年的推移（図 1)

次に昭和 57 年調査時と今回, 両方共 follow up がで きた 26 症例について術後から前回調査時までの期間お よび成績の推移をみた。26例中13例は変化なく，8例 が改善， 5 例が悪化していた．前回不可の 2 症例はい ずれも第 1 肋骨再生例で再手術により，それぞれ優と 可になっていた。ここで前回より悪化していた症例を みると 3 例は特に生活上での活動性を変化させている 訳ではないが，時々寒冷時にしびれや脱力感が生じて いた．また優から可になった症例はスポーツ等の活動 性の増加により症状出現し, 現在も挙上位での脱力感 やしびれが続いている．ここで前回調査時の術後経過 年数をみると，前回優で今回もその成績を維持してい 
たもの 5 例中 4 例までが前回の調査が術後 4 年以上の 症例であった，逆に前回優・良から悪化したもの 5 例 中 4 例までが，又良・可から改善したもの 6 例中 4 例 までが前回調査時が術後 2 年以下の症例であった.こ のことより術後 $1 \sim 2$ 年の間は成績が変化しやすく 3 年以上たつと安定するようであり, 術後の follow up もその点を考虑して少なくとも $3 \sim 4$ 年は充分に行な うべきであると思われる。

\section{ま と め}

1. 胸郭出口症候群の診断法につき述べた.

2 . 術後半年以上経過した当科開設以来の手術症例 の予後調査を行ない，74例中58例（78.4\%）に症状改 善がみられた。

3. 症状別改善度をみると肩および上肢の脱力, 上肢のしびれは良く改善されているが, 肩甲部痛の改 善度は悪い。

4. 術後 $1 \sim 2$ 年の間は手術成績が変わりやすく, 3 年以上たつと大体安定するようであるので，少なく とも術後 $3 \sim 4$ 年間は充分経過をるるべきである.

\section{文 \\ 献}

1）南川博道：胸郭出口症候群の臨床的および解剖学的 研究. 医学研究, 53:341-355, 1983.

2）南川博道，ほか：胸郭出口症候群の治療成績. 整形 外科と災害外科, $32: 77-81,1984$.

3）竹下 満：胸郭出口症候群の診断における臨床的, 解剖学的研究一腕神経叢造影について一. 医学研究, $56: 1-23,1986$.

4) Urschel, H.C.Jr., et al.: The technique of measuring conduction velocity for thoracic outlet syndrome. Pain in shoulder and arm, Publishers, M.N., 165, 1979.

質 問 九州大学 佐々木賀一

TOSの例では，心理的に問題のある人が多く，手 術をためらうことが多いが，先生の所では心理テスト など何かの check を行なっていますか.

\section{解 答福岡大学 南川 博道}

psychological factor の関与が考えられる症例では, 腕神経叢造影を含めて圧迫部位の確認を行ない, 又精 神科医による諸検查の結果を参考にして治療方針を決 めています。 